\title{
Consequences of Rorty's Pragmatism in Science
}

\section{Nalliely Hernández}

\section{OpenEdition}

\section{Journals}

Electronic version

URL: http://journals.openedition.org/ejpap/1074

DOI: 10.4000/ejpap.1074

ISSN: 2036-4091

\section{Publisher}

Associazione Pragma

\section{Electronic reference}

Nalliely Hernández, « Consequences of Rorty's Pragmatism in Science », European Journal of

Pragmatism and American Philosophy [Online], IX-2 | 2017, Online since 22 January 2018, connection on 02 May 2019. URL : http://journals.openedition.org/ejpap/1074 ; DOI : 10.4000/ejpap.1074

This text was automatically generated on 2 May 2019.

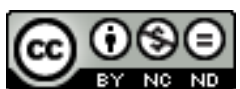

Author retains copyright and grants the European Journal of Pragmatism and American Philosophy right of first publication with the work simultaneously licensed under a Creative Commons Attribution-

NonCommercial-NoDerivatives 4.0 International License. 


\title{
Consequences of Rorty's Pragmatism in Science
}

\author{
Nalliely Hernández
}

\section{The Rortyan Conception of Science}

1 Even though the conception of science was a topic very often analysed in Rorty's writings, his approach always attempted to overcome a science-centred perspective of philosophy and culture. Thus, Rorty insisted on characterising science and knowledge instrumentally, although he was never particularly interested in deepening into these perspectives to construct an explicit and systematic philosophy of science and its consequences for the practices and conceptions of science itself. Nonetheless, his epistemological reflections on science are fundamental and extensive enough to develop a philosophical viewpoint of it with a pragmatist and post-positivist character. Such viewpoint allows us to dissolve a substantial part of the philosophical problems of scientific practice becoming a useful tool to deal with contemporary challenges and issues. At the same time, it concurs with the most interesting contemporary proposals which avoid some classical dichotomies in the field.

2 Throughout his work, there are two main sources to outline the image of science that Rorty provides us in his philosophy. The first and more general source is his well-known epistemological analysis of Modernity and Contemporary Philosophy. The second one is his particular characterization of scientific nature when he suggests a healthy and convenient relation between science and culture.

In the former, the American philosopher reveals the historical and optional nature of the modern epistemological problems and perspectives. He further contends that the metaphysics resulting from such a tradition is exhausted after the copious and unsolved epistemological discussions about truth or rationality and the historical and sociological studies of science during the twentieth century. As a result, Rorty replaces the representational character of knowledge with an instrumental view, which does not need a philosophical theory. He goes on to assert a deflationist perspective of truth, an anti- 
essentialist assessment of reality and an ethnocentric viewpoint of justification and rationality.

4 Consistent with these perspectives, Rorty provides a picture of science drawn from his Peircean description of beliefs and inquiry as habits of action, and it is specified in his notions of scientific method, rationality and objectivity. All these conceptions together lead us to the rejection of empiricism as a foundation of scientific knowledge, and to the embracement of a fuzzy, practical and sociological frontier of science. In short, what Cornel West calls Rorty's "Emersonian sensibilities" undermines the authority of science by demythologizing the tradition that provides it a culturally privileged position (West 1989: 204).

5 As I said, Rorty, following Peirce, conceives beliefs as habits of action that we attribute to organisms (people) to predict or retrodict their behaviour. In this way, beliefs guide actions, which produce more actions and then more beliefs in an endless process. Some of the new beliefs create tensions or contradictions with the old ones, so we can eliminate some other belief or create a new one to reduce or avoid these tensions. Therefore, beliefs are guides of actions, which compose a web of relations that is constantly evolving and reweaving these relations (Rorty 1991a: 93). Consequently, every object is always contextualized because it is part of such a web. This process also explains the nature of inquiry. Inquiry implies a large-scale and deliberate reweaving of our beliefs to integrate new ones. In his words: "They (beliefs) may lead to 'reflex' actions or they may initiate scientific breakthroughs." (Rorty 1991a: 94). Then, if the number of changes in the web continues to increase, at some point we can speak of the "recontextualization" of the object. This recontextualization can be perfectly conceived as a new scientific theory, the development and description of which implies a radical reconfiguration of the positivistic conception of science.

6 In particular, Rorty points out how philosophy since Modernity has been looking for a philosophical explanation of scientific success. The metaphor that provided an attractive yet ambiguous answer to this question involves the Galilean idea that a mathematical and reductionist vocabulary was the discovery of Nature's own language, and thus, it is an image of the way things really and truly are. Then, this philosophical tradition interpreted the success and usefulness of Galileo's ultimate terminology as a signal of its intrinsic reality because of its lack of human interest or moral significance (Rorty 1982: 191-3). In this way, scientific generalizations embracing efficient predictions provided a philosophical content to the conception of scientific method. Since then, prediction, control and what Rorty calls Galilean axiological neutrality become a metaphysical process which screens subjective aspects of our descriptions, even if it is unclear in the history of science which general but not trivial procedures compose such a method (Rorty 1982: 194).

7 Unlike this philosophical view, and according to the concrete development of scientific theories, Rorty says, scientists use the same obvious procedures that everybody uses in many activities. They sometimes overlook counterexamples, contradict a criterion, make assumptions and guesses, etc. Of course, they also make interesting inferences and try to follow organized and clear procedures for testing their ideas, but this is quite different from having a reductionist and/or formal language without evaluative terms as a token of scientificity and reality, which seems to remain an impossible task. In his words:

In that sense, to have a method was simply to have a good comprehensive list of topics or headings-to have, so to speak, an efficient filing system. In its post- 
Cartesian philosophical sense, however, it does not mean simply ordering one's thoughts, but filtering them in order to eliminate "subjective" or "noncognitive" or "confused" elements, leaving only the thoughts which are Nature's Own. (Rorty 1982: 194)

8 In contrast, according to him, there is no specific logic of scientific method, only instituted and historical procedures that influence our choice of theories at any given stage of inquiry. This statement embodies the idea that there is no distinctive scientific rationality that justifies a special relation of science with reality. In this sense, one of the main goals in philosophy of science became that of achieving a precise theory of scientific reasoning and argumentation; a theory that would abstract general patterns from the debates "over genes and spectra and fields and delinquency" (Rorty 1991b: 53), guiding as independent criteria for a scientific demarcation.

9 However, as the history of science has shown us from Kuhn or Feyerabend's studies, it seems that there are no such properly scientific general patterns as a set of abstract criteria for applying. Decisions that scientists make that generate changes in theories are reweaves of beliefs to attain better control and prediction of phenomena, but this is not a specific kind of intelligibility. They are familiar procedures of justification used by a given discipline or community. Indeed, for Rorty, rationality is not a matter of abstractly applying criteria. Consistent with this perspective, we can explain observations, theories and decisions made by scientists by reference to the intellectual and social history, as well as by reference to their respective psychologies, sensibilities and context.

In the same way, Rorty states that following the metaphor initiated by Galileo, Newtonian Physical Science became a model for the intellectual of modernity, so this prototype of knowledge should be followed by the establishment of social, political and economic institutions because of its access to nature and its correspondence to reality itself. Therefore, parallel to the method and scientific traditional conceptions, objectivity means that we must "step outside our community" in the light of something that transcends it. In other words, as long as scientific inquiry is understood as a way to find the "underlying structures" or "culturally invariant factors" or "biologically determined patterns" of reality, objectivity is understood as something common with every other possible human community or independent of any particular community (Rorty 1991c: 22).

11 Nonetheless, once he had dismissed the epistemological distinctions of method and rationality, objectivity is reduced to intersubjectivity. It is grounded in as broad a community agreement as possible. Thus, the tools of science are not less "merely" human than those, which make beauty or justice possible (Rorty 1991b: 58). This means that objectivity works the same way for physics as for literary theory, because the difference between them is relative to the goal of each discipline, and science requires more agreement than arts according to its predictive intentions (Rorty 1998: 139). Indeed, Rorty dissociates this possibility of control of phenomena from being non perspectival or mind-independent.

12 Now, even though Rorty redefined these notions involved in scientific development, we can still contend that experience has a crucial role to play in science that it does not have in other languages or practices. Contemporary philosophy usually preserves a very intuitive and common idea that science deals with hard facts. According to this popular empiricist perspective, this hardness of facts is a properly scientific distinction. However, Rorty follows the viewpoint that connects Sellars to Brandom, which proposes 
substituting the conception of perceptive experience for the conception of noninferential statements caused by the physiological conditions of the sensorial organs, this is, that physical stimuli have a causal rather than rational role in the production of beliefs.

In this way Rorty (1991d) offers an analysis of science that understands the supposed hardness of facts as a result of previous agreements within a community. We respect the rules of a certain language game whose purposes require broad agreement and homogeneity, and those rules are cultural products.

14 As a result, there are no epistemological distinctions between scientific procedures or objects and other social practices and stuffs. Rorty makes a description in which every fact is a social institution and, at the same time, it is not arbitrary or merely conventional as opposed to natural, because science is not natural in kind. In the same way, some of these institutions are more internally diverse, more complicated or, as he says, "more quarrelsome about desiderata" (Rorty 1991d: 84). Most of the time, science has more instituted procedures, but this is explained by its focus on control and prediction, as I stated above. Even so, it can also be as revolutionary and as inventive as politics and arts. It has a practical and sociological boundary; therefore, the questions about the sentences that are "made true by the world or reality" are definitely discarded and, then, "literary texts are not squishier than molecules" (Rorty 1991e: 40).

\section{Science as Power: Rortyan Connections and Usefulness}

15 Knowledge as a web of useful beliefs that are justified in a particular time is relative to the different purposes a culture or a community is engaged with. However, the ends or purposes are always evolving, mainly according to a set of values and forms of social organization. Consequently, from this perspective there is an imminent and fundamental shift in concerns from epistemological to ethical-political in scientific practice. This shift is mostly consistent with Feyerabend's perspective of scientific nature as well as with the Baconian perspective that knowledge is not separable from power, and so, it also resonates with the Foucaultian epistemes.

16 Therefore, this whole framework provides us not only with a new and clearly enclosed place of science in cultural development, but also with a new perspective for describing and explaining scientific theories and their connection with other vocabularies as a part of a cultural politics. Rorty clearly states that if reductionist and mathematical language has been a useful tool for prediction, there can be better options of means and ends in arts, politics, or morals. As a result, he rather supports a healthy plurality of languages, which affords different tools for each new aim.

17 One of the most important political implications of this fuzziness of science and its constraint to some specific goals in social life is a reformulation of the Deweyan deconstruction of the culture-nature distinction. ${ }^{1}$ If science is not a natural kind, and there is no reality in itself, then there is also no human nature in itself. Therefore, according to Rorty (2004), the old question about our natural or cultural nature became irrelevant or sterile, and science cannot (or should not) provide us with a definitive answer about what we really are. As he emphatically states in his article "Philosphyenvy," physical, chemical and biological discoveries can tell us interesting things about 
how our bodies and brains work, but they cannot tell us "what sort of behaviour [to] encourage" (Rorty 2004: 21) or how we should live, nor can it provide a foundation for organizing our social lives. From this post-positivistic perspective of science, the latter has worn-out its usefulness for political ends because it is not the foundation of culture, and it is neither an example of social cooperation nor public deliberation different from any other discipline. ${ }^{2}$

In this way Rorty is partially connecting the Deweyan and Foucaultian perspectives, ${ }^{3}$ refusing the traditional conceptions of knowledge, science, and its epistemological categories, and redefining them as a product of history and social processes. If there are no universal structures of reality, science becomes a set of traits of power arrangements that can be desirable or undesirable according to different purposes, and in natural or social science their genealogical narratives are useful for lightening and valuing means as well as ends. In this new light we can explore scientific narratives, structures and their close connections to social development by exposing different key cultural features that condition and predetermine it. At the same time, we can also show how some scientific vocabularies justified a specific political project, legitimized by putative traditional scientific objectivity and rationality.

In addition, this Rortyan perspective of science is quite close to the most interesting contemporary proposals in philosophy of science. In recent decades, taking historicism and the sociological perspectives inherited from Kuhn and Feyerabend's views seriously, an important amount of work has been made. However, even though many authors have been exploring and recognize science as a value-laden activity, ${ }^{4}$ many of them insist on an external role of non-epistemic values in the stages of science. This external-internal distinction in scientific development implies that scientific development demands a rational critique independent of the social context, and subsequently, this context is only contingently involved in it. ${ }^{5}$ Nonetheless, other authors such as Heather Douglas (2007) state that the epistemic-non-epistemic distinction is not clear enough to support a normative difference in scientific practice. According to her, non-epistemic values are logically needed for reasoning in science, even in the internal states of the process. This allows her to argue that there is nothing necessary about the link between axiological neutrality and objectivity, so that we can discard the value-free meaning of the latter (Douglas 2007: 131). Moreover, such a perspective enables her to develop a conception of objectivity in science taking into account different scientific virtues in different situations, just as Rorty does.

On the other hand, Arthur Fine (1986) in what he calls the "Natural Ontological Attitude" tries to reject the assumptions of the debates on scientific realism and anti-realism that bring unnecessary and unjustified philosophical interpretations of science, and according to Rorty this attitude is closely connected to his own suggestion that "Reality as it is in itself" is just another way to insist on God's authority, or that the idea "that Physics gets you closer to reality than morals as an updated version of the priests' claim to be in closer touch with God than the laity" (Rorty 2007: 134). Thus, his view of science implies that it is not philosophically different from the rest of culture in any meaningful way. ${ }^{6}$ In a similar way, Lawrence Sklar (2000) contends that the best arguments are local and contextual, and they do not appeal to universal philosophical principles.

However, perhaps one of the most radical and closest approaches to Rortyan perspective is Harold Kincaid's contextualism (2007). In it, he states that there are no global criteria for deciding which beliefs or principles of inference have epistemic priority. Justification 
in science is relative to a specific context specified by the questions to be answered. Just as Rorty, he rejects foundationalist approaches in epistemology and he contends an antiessentialist view about theories. As a result, there is no special set of rules with an inherent epistemological status (Kincaid 2007: 223).

Likewise, Hugh Lacey develops the interesting idea that objects are simultaneously objects of materialist understanding and objects of social values; so that we structure the world in ways that partially represent the embodiment of such social values (Lacey 1999: 106-7). In particular, he states that adopting modern values of control and prediction has been reinforcing the idea of gaining understanding under materialist strategies, so that objects are grasped in order to become "objects of control," thereby subordinating other social values, such as moral values, and implicitly informing practices that serve some kind of specific values, for example, economic values. This reinforcement consolidated control and prediction values and their materialist characterization as features of how the world "really is." In this way, he says, "exercising control over things has become considered as a value unsubordinated to other social values" (Lacey 1999: 112), and daily life and institutions have become dominated by it. Conversely, he states similarly to Rorty that: "Not every effective intentional interaction with the world is an instance of control." (Lacey 1999: 111). As both of them state, there is no argument independent of success for interpreting science as greater comprehensiveness of reality. Moreover, prediction and control as signs of reality ignores other fundamental dimensions of reality, and it easily hides social, ethical or political possibilities embodied in them (Lacey 1999: 137).

In summary, the Rortyan perspective implies an ethical and political turn, which connects to the latter specific perspectives on science with a broader post positivistic conception of culture, creating a useful tool for analysing scientific theories in such often ignored dimensions. It also shows what Cornel West (1989) named post-structuralist resonances, but complementing it with an insightful perspective of scientific activity and its legitimation.

\section{Some Scientific Examples in the Rortyan Landscape}

Finally, I analyse some examples that illuminate the accuracy and usefulness of this perspective. These examples show in different dimensions and in particular cases, some of the statements about science I previously pointed out from Rorty's writings and its consequences.

The first example involves the origin of the Principle of Complementarity in Quantum Mechanics. This principle, along with the Heisenberg's Principle of Indeterminacy, is the core of the Copenhaguen Interpretation of Quantum Physics, and was elaborated by Niels Bohr in 1927. At the end of 1925 there were two different well-founded mathematical structures that accounted for atomic phenomena: the wave and matrix mechanics. However, those structures had different guiding principles and methods; moreover, they emphasized different features of atomic events, especially continuity and discontinuity, an intuitive visualization and an anti-intuitive abstraction, respectively (Schrödinger 1982: 45).

In addition, the use of the classical conceptions of wave and particle for describing atomic results led to unavoidable contradictions because the same object sometimes seemed to 
be a particle and sometimes seemed to be a wave. This scenario was completely confusing for physicists because Nature seemed to have an irrational and inconsistent behavior. ${ }^{7}$ Heisenberg remembered the question he repeated to himself again and again: "Can nature possibly be as absurd as it seems to us in these atomic experiments?" (Moore 1966: 147). Eventually, it became clear that quantum equations lack an interpretation using the ordinary and classical concepts and images (Cassidy 1992: 227). In this context, Bohr elaborated the Principles of Complementarity to provide Quantum Theory with a new logical and conceptual framework for interpreting atomic events. That principle establishes the wave and particle duality, such that both conceptions are necessary but mutually exclusive to account for the electron's behaviour: it is corpuscular or wavelike depending on the experimental device we use to measure it. ${ }^{8}$

The origin of this principle can be traced back to formalism and empirical results. However, they are necessary but insufficient conditions to explain its occurrence. Indeed, through his writings after 1927 Bohr develops his original philosophical perspective concerning his general conceptions of nature, experience, language, phenomena or knowledge, as well as his conceptions of objectivity and truth. ${ }^{9}$ In particular, he states that experience allows us to establish laws for understanding natural phenomena; however, these laws usually modify the guidelines which order the very experience. Therefore, a conceptual framework does not have a structure or configuration that cannot be modified. For him, science does not look for an a priori and determined reality, but it develops methods to expand and arrange human experience in a consistent and unambiguous way (Bohr 1958). This is the basis of objective knowledge. He is also convinced that we need classical categories of wave and particle to make an intuitive description of quantum events, because our necessary and normal forms of perception are in the classical language (Feyerabend 1962: 228-31). These general ideas allowed him to develop the idea of Complementarity.

Thus, in philosophy of physics different authors connect the Principle of Complementarity with different ideas of Bohr's psychological and intellectual history. Some scholars of Bohr have established different influences from psychology and philosophy that allowed him to formulate this Principle. Particularly, the influence of the philosopher Harald Høffding is noteworthy, and through him, there are important traces of Kant, Kierkegaard or James' ideas. ${ }^{10}$ For example, Rui Moreira develops the thesis that Høffding elaborated a principle of complementarity in psychology between a priori Kantian sensibility and understanding in a similar way to what Bohr made in Physics, as incompatible but necessary categories. He also conceives that continuity and discontinuity are incompatible necessities of spirit. This combination between irreconcilable and necessary features of reality is what distinguishes Høffding's perspective and characterises Bohr's interpretations of atomic events. ${ }^{11}$ In addition, another possible influence, even if it is less clear, is from William James. In his Principles of Psychology he states a principle of complementarity between conscious and subconscious, also in a way that is analogous to the Bohrian complementarity. ${ }^{12}$ Even if Bohr used this relation as an analogy to elaborate his quantum interpretation, there is no clear evidence that he had read James' ideas before he stated the principle of complementarity. Still, Bohr, as well as his colleague Werner Heisenberg, has an empiricist attitude in which Quantum Theory only explains or accounts for observable events, so there is no ontology beyond measurable entities. This attitude has often been connected to a Pragmatist criterion of truth in the Copenhagen Interpretation. 
29 In summary, those studies outline Bohr's interpretation of quantum events as a framework influenced by a philosophical and psychological attitude that was a result of his cultural and intellectual environment, thereby supporting the Rortyan statement that there is no explanation in science directly stemming from hard facts; physical stimuli on atomic experience had a causal role in the production of beliefs; experiments and predictions were not enough to give a consistent interpretation of atomic events; the use of additional assumptions and relations was, indeed, necessary. Similarly, these examples show that justification comes from particular rules that are followed in a specific context. The best evidence for this statement is the permanent opposition that Complementarity has faced and the diverse interpretations in conflict that Quantum Mechanics has had so far. ${ }^{13}$

30 The second example, and perhaps the most politically interesting, concerns the origin of molecular biology and in particular of genetics. ${ }^{14}$ This origin has been widely studied by historians and philosophers alike. They have pointed out a set of social factors which had an major influence on the institutionalization of the gene's paradigm during the first half of the twentieth century. Although the results are controversial, an important part of these studies use the Foucaultian relation between truth and power to account for the economical and ideological factors which promoted this model. ${ }^{15}$ Some of these analyses suggest that a technocratic environment in a liberal and pragmatic American society enabled, through different structures and institutions, its epistemological hegemony.

31 Maybe the most often mentioned and analysed institution is the Rockefeller Foundation, which sponsored numerous life sciences projects during the 1930s, pervading in the academic perspectives, strategies and politics which guided the scientific development in this field. According to Lily E. Kay (1993), the Foundation had, on the one hand, an economic interest in the nuclear model of inheritance for pushing the productivity growth through crossbreeding of plants and animals, and on the other, an ideological interest for achieving a social control through inheritance to guide human behaviour according to a system of Protestant and conservative values. The Foundation and some groups close to it were looking to realize a world of social prosperity and progress using human engineering.

It is well known that the model of the gene as the building-block of life obeyed an ontological and methodological analogy with the model which takes the atom as the building-block of matter in a reductionist and mechanistic view of life, which emphasised its conceptual unity. The gene is defined as the fundamental unity of life, and is explored through mutations and discontinuous changes. Thus, all the biological diversity is the result of a set of a few laws and principles. In this sense, there was a subtle association of these epistemological and ontological features of genes, perceived as direct causes of the macroscopic characteristics (physiological or psychological) of every living creature, with some ideological perspectives of social life. For example, for some Marxist scientists the reductionism was associated with the capitalist contradictions in the social system. However, for the most conservative perspectives, such as that of the Rockefeller Foundation, it portrayed psycho- and socio-biology as a symbol of control and social progress because it allowed connecting, albeit potentially and ambiguously, small material unities to the personality control conceived by genetics. Some perspectives supported a social physics in a Comptian sense and this reductionist and mechanistic model linked the "atom" of life to these psycho- and socio-biological perspectives which resulted more attractive than the holistic and more complex alternatives. 

scientific cultures in different countries, such as the French nationalism, which supported a Lamarckism and a more physiological perspective of inheritance, the American liberalism more committed to nuclear genetics, and the German statism connected to an embryologist point of view. This gives a partial account of the French and German opposition to the reductionism of the nuclear model in spite of its predictive success (Mayr 1982: 732). be complemented with the legitimation that it had due to its similarity with the atomic model in physics. In that way, the chromosomal theory of inheritance was linked to an ideal of neutral science founded on the scientific metaphysical tradition to support its objective nature, even though it was connected with a set of social values, as the aforementioned historical and sociological studies show. In summary, the nuclear epistemological frame resulted in a useful language for some social perspectives, mainly in America. It was a vocabulary that envisioned and impelled economic profit as a result of the crossbreeding of plants and animals as well as the ideological project of human engineering intended to develop a psycho- and socio-biology for ruling social organization, this is, the eugenic perspective to avoid undesired features in human behaviour. ${ }^{16}$ Thus, this conception of life enabled some particular goals and these goals outlined a conception of life. In summary, the outlined epistemological model of the gene supported, indirectly and not unequivocally, some values in different ways: from the conception of objectivity and scientific rigor traditionally attributed to physical science to the different social aims of some groups that this model seems to make easier. At the same time, some cultural environments seemed to facilitate more one model than other.

The former elements outline a general anatomy of the conversion of some ideological factors into cultural and socio-political ones that promote a given model. It can be seen how social and epistemic values are interconnected in this scientific episode, and how the conception of the gene became, during its early development, a set of both facts and values at the same time. This resonance between facts and values supports the Rortyan critique to the intended axiological neutrality in scientific language and illuminates the shift to the ethical and political perspective of science.

This case is particularly interesting and important in the current biotechnological discussions concerning the transgenic debate, the psychochemical approach to human behaviour, and all the ethical issues about genetics and biology in general (nutrition, psychiatry, etc.). The Rortyan perspective in connection with the other proposals I pointed out allows a wide and complete analysis of science in those dimensions inherent to basic science that is unavoidably connected with ethical and political ends, and it avoids a simplified, neutral and objective picture of it that is only well or poorly implemented in our societies. At the same time, and most important, it confines scientific utility to some particular human projects, becoming clear that for some vocabularies or practices, such as morals or politics it is better to attain different goals from prediction and control.

37 I think that Rorty missed some of the consequences of his own perspective, perhaps because he was not interested in specificities about science, or perhaps because he was more optimistic or naive in relation to power than other thinkers. But as I said at the beginning of this article, his proposal suggests an interesting way of analysing scientific practices, theories, and public policies of it that is more radical and advantageous than 
other perspectives. It also successfully connects the most interesting external and internal proposals of contemporary scientific views in philosophy and provides a fresh reference for us to better understand the way contemporary scientific views are embodied in our network of beliefs.

\section{BIBLIOGRAPHY}

BOHR Niels, (1934a), Atomic Theory and the Description of Nature, Cambridge, Cambridge University Press.

BOHR Niels, (1934b), "The Quantum Postulate and the Recent Development of Atomic Theory," in Atomic Theory and the Description of Nature, Cambridge, Cambridge University Press, 52-91.

BOHR Niels, (1958), Atomic Physics and Human Knowledge, New York, John Wiley \& Sons.

BOHR Niels, (1963), Essays 1958-1962 on Atomic Physics and Human Knowledge, New York, John Wiley \& Sons.

CASSIDY David C., (1992), Uncertainty. The Life and Science of Werner Heisenberg, New York, Freeman. DOPPELT Gerald D., (2007), “The Value Ladenness of Scientific Knowledge," in Kincaid Harold, Dupré John \& Wylie Alison (eds.), Value-Free Science? Ideals and Illusions, New York, Oxford University Press, 188-217.

DOUGLAS Heather, (2007), "Rejecting the Ideal of Value-Free Science," in Kincaid Harold, Dupré John \& Wylie Alison (eds.), Value-Free Science? Ideals and Illusions, New York, Oxford University Press, 120-39.

FEYeRABEND Paul, (1962) "Problems of Mycrophysics," in Colodny Robert G. (ed.), Frontiers of Science and Philosphy, Pittsburgh, University of Pittsburgh Press, 189-283.

FINE Arthur, (1986), “The Natural Ontological Attitude," in The Shaky Game, Chicago, 112-35. HERNÁNDEZ Nalliely, (2017), “Una defensa de la 'prioridad ontológica de lo social': epistemología e ideología en el modelo nuclear de la herencia y en el origen de la biología molecular," Contrastes. Revista Internacional de filosofia, XXII (2), 39-58.

JAMES William, (2007), The Principles of Psychology, Volume 1, New York, Cosimo.

JAMMER Max, (1966), The Conceptual Development of Quantum Mechanics, New York, McGraw Hill. KAY Lily E., (1993), The Molecular Vision of Life. Caltech, the Rockefeller Foundation and the Rise of the New Biology, New York, Oxford University Press.

KAY Lily E., (1997), "Rethinking Institutions: Philanthropy as an Historiographic Problem of Knowledge and Power," Minerva 35 (3), 283-93.

KINCAID Harold, (2007), “Contextualist Morals and Science," in Kincaid Harold, Dupré John \& Wylie Alison (eds.), Value-Free Science? Ideals and Illusions, New York, Oxford University Press, 218-38. KINCAID Harold, DUPRÉ John \& Alison WYLIE (eds.), (2007), Value-Free Science? Ideals and Illusions, New York, Oxford University Press. 
LACEY Hugh, (1999), Is Science Value Free? Values and Scientific Understanding, New York, Routledge. MAYR Ernst, (1982), The Growth of Biological Thought. Diversity Evolution, and Inheritance, Massachusetts, Harvard University Press.

MOORE Ruth Ellen, (1966), Niels Bohr: The Man, His Science, and The World They Changed, Cambridge, MIT Press.

MOREIRA Rui, (2004), "Ciência e Irracionalidade," in Chitas Eduardo \& Serrão Adriana Verissimo (eds.), Razão e Espírito Científico, Lisboa, Edições Duarte Reis, 63-74.

RIOJA Ana, (2002), "Sobre Ondas y Corpúsculos: Un Punto de Vista Lingüístico," in Rivadulla A. \& Mataix C. (eds.), Física Cuántica Y Realidad, Universidad Complutense de Madrid, 135-54.

RORTY Richard, (1982), "Method, Social Science and Social Hope," in Consequences of Pragmatism, Minneapolis, University of Minnesota Press, 191-209.

RORTY Richard, (1991a), "Inquiry as recontextualization: An anti-dualist account of interpretation," in Objectivity, Relativism and Truth. Philosophical Papers Volume 1, Cambridge, Cambridge University Press, 93-110.

RORTY Richard, (1991b), “Is Natural Science a Natural Kind?,” in Objectivity, Relativism and Truth. Philosophical Papers Volume 1, Cambridge, Cambridge University Press, 46-62.

RORTY Richard, (1991c), "Solidarity or Objectivity," in Objectivity, Relativism and Truth. Philosophical Papers Volume 1, Cambridge, Cambridge University Press, 21-34.

RORTY Richard, (1991d), “Text and Lumps," in Objectivity, Relativism and Truth. Philosophical Papers Volume 1, Cambridge, Cambridge University Press, 78-92.

RORTY Richard, (1991e), "Science as Solidarity," in Objectivity, Relativism and Truth. Philosophical Papers Volume 1, Cambridge, Cambridge University Press, 35-45.

RORTY Richard, (1998), “The Very Idea of Human Answerability to the World: John McDowell's Version of Empiricism," in Truth and Progress. Philosophical Papers Volume 3, Cambridge, Cambridge University Press, 138-52.

RORTY Richard, (2004), “Philosophy-Envy," Daedalus, 133, 4, 18-24

(doi:10.1162/0011526042365537).

RORTY Richard, (2007a), "Philosophy as a Transitional Genre," in Philosophy as Cultural Politics. Philosophical Papers 4, Cambridge, Cambridge University Press, 89-104.

RORTY Richard, (2007b), “A Pragmatist View of Contemporary Analytic Philosophy," in Philosophy as Cultural Politics. Philosophical Papers 4, Cambridge, Cambridge University Press, 133-46.

SAPP Jan, (1987), Beyond the Gene. Cytoplasmic Inheritance and the Struggle for Authority in Genetics, New York, Oxford University Press.

SCHRÖDINGER Erwin, (1982), Collected Papers on Wave Mechanics, New York, Chelsea Publishing Company.

SKLAR Lawrence, (2000), Theory and Truth: Philosophical Critique within Foundational Science, Oxford, Oxford University Press.

TORRES Aalejandro Gabriel \& Charles A. HOBBS, (2015), "The Intertwining of Culture and Nature: Franz Boas, John Dewey, and Deweyan Strands of American Anthropology," Journal of the History of Ideas, 76 (1), 139-62. 
WEST Cornel, (1989), The American Evasion of Philosophy: A Genealogy of Pragmatism, The Wisconsin

Project on American Writers (doi:10.1017/CB09781107415324.004).

\section{NOTES}

1. The culture-nature relationship is a theme found throughout Dewey's works, from at least as early as the 1890 s to his last writings in the early '50s. However, the culture-nature unity assumed by the philosopher was particularly evident in works of Dewey from the early and mid-1920s, including Human Nature and Conduct and Experience and Nature (See also: Torres \& Hobbs 2015).

2. Rorty explains that a good example of social cooperation and public deliberation can come in the same way from engineers, carpenters as well as from scientists in: Rorty 2007a.

3. See: Rorty 1982.

4. For example, see: Kincaid, Dupré \& Wylie 2007.

5. See: Doppelt 2007.

6. Even though Rorty disagrees with Fine that the realist is irrational or lacks rational support such as the theist does, and he does not share his idea of ontological commitment (for the discussion of Rorty about Fine's perspective, see: Rorty $2007 \mathrm{~b}$.

7. To see the problems of the wave and corpuscular interpretation of quantum mathematical structures see: Rioja 2002.

8. According to Bohr, this complementary nature of quantum events is quantitatively expressed in the Uncertainty Principle of Heisenberg. To see the complete explanation of Complementarity: Bohr 1934b.

9. The intellectual development of Bohr's ideas is chronologically collected in three collections of writings: Bohr 1934a, 1958, 1963.

10. Jammer points out the importance of Kierkegaard's idea, elaborated by Høffding, that humans cannot be an impartial spectator or an impersonal observer, because we are always active participators of knowledge: (Jammer 1966: 173).

11. To see all the connections between Høffding and Complementarity: Moreira 2004.

12. In the section of his book about unconsciousness of hysterics, James states that there are some cases in which conscience can be split in two coexistent parts, which share the same object of knowledge, but mutually ignore each other. See: (James 2007: 200-6).

13. For example: supporters of Bohmian Mechanics or supporters of the statistical interpretation of Quantum Theory.

14. I develop this example in extensively in my article (2017).

15. For example: Sapp 1987.

16. However, these are not the only values connected to the model, but the most obvious.

\section{ABSTRACTS}

The aim of this article is to outline a pragmatist image of science following Rorty's discussions and critics of epistemology and to develop some consequences of it in the philosophical analysis and its relations to culture. I will deal with some aspects of how scientific practice is construed 
and understood, and also outline the shift in Philosophy of Science from epistemological to ethical-political concerns that are implied in his proposal. I will contend that this perspective suggests an interesting way of analysing scientific practices, theories, and public policies of it. Furthermore, I will suggest that it successfully connects the most interesting proposals of contemporary scientific views in philosophy. Finally, I will use some examples in physics and biology to illustrate my assertions.

\section{AUTHOR}

\section{NALLIELY HERNÁNDEZ}

Universidad de Guadalajara

nallie3112[at]hotmail.com 